\title{
WATERMELON SENSITIVITY TO RESIDUAL OF PRE-EMERGENT HERBICIDE APPLIED IN SOYBEAN CROP
}

\section{SENSIBILIDADE DA MELANCIA AO RESIDUAL DE HERBICIDAS PRÉ-EMERGENTES APLICADOS NA CULTURA DA SOJA}

Samia Rayara de Sousa Ribeiro ${ }^{\mathrm{a}}$, Jéssica Ferreira Lourenço Leal ${ }^{\mathrm{a}}$, Amanda dos Santos Souza ${ }^{\mathrm{a}}$, Junior Borella ${ }^{\mathrm{a}}$, Gledson Soares Carvalho ${ }^{\mathrm{a}}$, Caio Victor Lopes Pereira $^{\mathrm{a}}$, Camila Ferreira de Pinho ${ }^{\mathrm{a} *}$

${ }^{\text {a } D e p a r t a m e n t o ~ d e ~ F i t o t e c n i a, ~ U n i v e r s i d a d e ~ F e d e r a l ~ R u r a l ~ d o ~ R i o ~ d e ~ J a n e i r o, ~ R i o ~ d e ~ J a n e i r o, ~ B r a s i l . ~}$

*Autor correspondente: camilafepi@hotmail.com

\section{INFORMAÇÕES DO ARTIGO \\ Histórico do artigo:}

Recebido: 26 Março 2019.

Aceito: 17 Junho 2019.

Publicado: 25 Agosto 2019

Palavras-chave/Keywords:

Bioindicador/Bioindicator.

Carryover/Carryover.

Citrullus lanatus/Citrullus lanatus.

Direito Autoral: Este é um artigo de acesso aberto distribuído sob os termos da Licença Creative Commons, que permite uso, distribuição e reprodução irrestritos em qualquer meio, desde que $\mathrm{o}$ autor $\mathrm{e}$ a fonte originais sejam creditados.

\section{Citação deste artigo:}

RIBEIRO, S. R. S.; LEAL, J. F. L.; SOUZA, A. S.; BORELLA, J.; CARVALHO, G. S.; PEREIRA, C. V. L.; PINHO, C .F. Watermelon sensitivity to residual of pre-emergent herbicide applied in soybean crop. Revista Brasileira de Herbicidas, v. 18, n.2. 2019.

\begin{abstract}
The long-lasting residual effect of herbicides depends on the soil and molecule characteristics; however, the bioactivity of the herbicide can cause damage to the crop in rotation/succession. The most common way to identify the presence of herbicides in the soil is by the implantation of bioassays that uses a susceptible species to herbicidal molecules as an indicator of residues. The aim was to identify the sensitivity of watermelon as bioindicator to the pre-emergence herbicide residue used in soybean cultivation. The assay was carried out in a greenhouse, in $3 \mathrm{~L}$ pots, in a randomized block design, with four replicates, in a factorial scheme of $3 \times 4+1$, where factor A was the herbicides diclosulam, [imazapyr + imazapic], and metribuzin, and factor B the doses of commercial products $[1 / 8 \mathrm{D}, 1 / 4 \mathrm{D}, 1 / 2 \mathrm{D}$ and $\mathrm{D}$ (recommended label dose)] plus control treatment. Four watermelon seeds were sown in soil per pot after herbicide application. The variables were analyzed 30 days after the emergence of the plants: shoot length $(\mathrm{cm})$, length $(\mathrm{cm})$, root volume $(\mathrm{mL})$, shoot dry mass $(\mathrm{g})$ and root dry mass $(\mathrm{g})$. Watermelon seeds did not germinate in the treatments with sub-doses of the herbicides diclosulam and metribuzin, and the growth was reduced in the sub-doses of the herbicide [imazapyr + imazapic], showing the sensitivity of this species. The herbicides studied adequately exerted control in watermelon bioindicator plants. Watermelon has sensitivity to the herbicides diclosulam, metribuzin and the commercial mixture of the herbicides [imazapyr + imazapic], with the potential to indicate the residue of these herbicides in clayey soil.
\end{abstract}

\section{RESUMO}

O efeito residual duradouro de alguns herbicidas depende das características do solo e das moléculas, entretanto, a bioatividade do herbicida pode causar danos nas culturas em rotação/sucessão. A maneira mais comum de identificar a presença de herbicidas no solo, é pela implementação de bioensaios que utilizam uma espécie potencialmente sensível às moléculas herbicidas como indicador deste resíduo no solo. $\mathrm{O}$ objetivo foi identificar a sensibilidade da melancia como bioindicadora à resíduos de herbicidas pré-emergentes utilizados na cultura da soja. $\mathrm{O}$ ensaio foi conduzido em casa de vegetação, em vasos de 3 $\mathrm{L}$, em delineamento por blocos ao acaso, com quatro repetições, em esquema fatorial de $3 \times 4+1$, onde o fator A foram os herbicidas diclosulam, [imazapyr + imazapic] e metribuzin, e o fator $\mathrm{B}$ as doses dos produtos comerciais [1/8D, 1/4D, 1/2D e D (dose recomendada em bula)] e mais o tratamento controle. Foram semeadas quatro sementes de melancia por vaso, contendo solo argiloso, após a aplicação dos herbicidas. As variáveis analisadas 30 dias após a emergência das plantas foram comprimento de parte aérea $(\mathrm{cm})$, comprimento $(\mathrm{cm})$, volume de raiz $(\mathrm{mL})$, massa seca da parte aérea $(\mathrm{g})$ e massa seca de raiz $(\mathrm{g})$. Verificou-se que a melancia não germinou nos tratamentos com subdoses dos herbicidas diclosulam e metribuzin, e o crescimento reduziu nas subdoses do herbicida [imazapyr + imazapic]. Os resíduos de herbicidas estudados exerceram controle das plantas bioindicadora. Melancia possui sensibilidade aos herbicidas diclosulam, metribuzin e à mistura comercial dos herbicidas [imazapyr + imazapic], possuindo potencial para indicar resíduo destes herbicidas em solo argiloso. 
S. R. S. RIBEIRO et al.

\section{Introduction}

The use of herbicides contributes substantially to the expansion and development of agriculture worldwide. In Brazil, herbicides represent the mostly widely method used for weed management. Herbicides with prolonged soil bioactivity are important for crops that require a long period of total weed interference (PIRES et al., 2008; SANTOS et al., 2013). However, one of the major problems observed in the several crops has been the intoxication of non-tolerant successor plants caused by herbicides used during the cycle of the target crop, thus compromising the productivity of the subsequent crops used in rotation and/or succession (DAN et al., 2012).

The herbicide behavior in soils, as well as the residual effect, can be evaluated using plant species that show sensitivity to the product used, and it may be possible to determine the persistence of the molecules in the soil, the time of the residue with bioactivity and their environmental impact (BLANCO et al., 2010). Herbicide-sensitive plant species are commonly used in bioassays to determine the residual of the molecules in the soil because they are a simple, fast and low-cost method and do not require the use of other methods such as mass spectrometry and chromatography (LI et al., 2008; MELO et al., 2010).

The herbicide permanence period in the soil varies according to the sorption, leaching, degradation and transformation potential of these molecules, as well as their physical and chemical properties, which may directly influence their persistence (OLIVEIRA JUNIOR; REGITANO, 2009; PRATA et al., 2003).

Diclosulam acts by inhibiting the acetolactate synthase (ALS), the enzyme common to the biosynthesis of the branched-chain amino acids (valine, leucine, and isoleucine), indicated for the control of dicotyledons in presowing incorporated or in pre-emergence in the soybean crop (DYER ; WELLER, 2005). The herbicide presents a partition value $\left(\mathrm{K}_{\mathrm{D}}\right)$ considered low (117 ppm at $\left.\mathrm{pH} 5.0\right)$, acid ionization constant $\left(\mathrm{pK}_{\mathrm{a}}\right)$ of 4.09 , octanol/water coefficient $\left(\mathrm{K}_{\mathrm{OW}}\right)$ of 1.42 and half-life of 60 to 90 days, depending on the soil moisture and organic matter conditions (MONQUERO et al., 2013).

The formulated mixture of the herbicides [imazapyr + imazapic], acts by inhibiting the ALS enzyme. Belongs to the group of imidazolinones and has its action on weed control in pre-emergence in soybean and post-emergence in maize Clearfield ${ }^{\mathbb{R}}$. It has a residual and persistent characteristic, relatively soluble in the soil, besides being degraded slowly (DOVALA; MONTEIRO, 2013). The $\mathrm{pK}_{\mathrm{a}}$ values of the imidazolinone herbicides range from 1.3 to 3.9 (SENSEMAN, 2007). Microbial degradation is the main means of dissipation of imazapyr in soil and its half-life varies from 25-142 days depending on soil characteristics and environmental conditions, which, if favorable, increase the biodegradation of the molecules (SENSEMAN, 2007; KRAEMER et al., 2009). In general, imazapyr undergoes limited degradation under anaerobic conditions, increasing its persistence in hydromorphic soils and a residual effect on susceptible rice can occur even after 12 months after application (SOUZA et al., 2016).

Metribuzin is a selective herbicide of the triazinone group, used to control weeds of broadleaf and some grasses in pre-emergence of the crop in conventional planting, and can also be used in no-tillage. The herbicides of this group act by inhibiting photosynthesis through a blockage in photosystem II when they bind to the site of quinone $B\left(Q_{B}\right)$ in the $\mathrm{D} 1$ protein, preventing the binding of plastoquinone, blocking the electron transport in the photochemical phase of photosynthesis (TROPALDI et al., 2015). Metribuzin presents high solubility in water $\left(1100 \mathrm{mg} \mathrm{L}^{-1}\right)$; the dissociation constant $\left(\mathrm{pK}_{\mathrm{a}}\right)$ is 1.0 , being easily leached in the soil, so its use is not recommended in sandy soil and/or with a low level of organic matter. It has a half-life of 30 to 60 days depending on soil texture and climatic conditions (SILVA JUNIOR et al., 2015).

In view of the recurrent use of pre-emergent herbicides together with the need of identifying susceptible species to these compounds, the aim of this study was to verify the sensitivity of watermelon (Citrullus lanatus) to residual of diclosulam, [imazapyr + imazapic] and metribuzin herbicides applied in pre-emergence in soybean crop.

\section{Material and Methods}

The experiment was carried out in a greenhouse from January to February (2017), under natural light and temperature conditions in a randomized block design with four replicates, in a $3 \times 4+1$ factorial scheme, where factor A was the diclosulam herbicide (Spider 840 WG, WG, 840 g a.i. $\mathrm{kg}^{-1}$, Dow AgroSciences), [imazapyr + imazapic] (Soyvance Pre, WG, $175+525 \mathrm{~g}$ a.i. $\mathrm{kg}^{-1}$, Basf) and metribuzin (Sencor 480, SC, 480 g a.i. $\mathrm{L}^{-1}$, Bayer), and factor $\mathrm{B}$ doses of the products in $\mathrm{g}$ a.i. $\mathrm{ha}^{-1}[1 / 8 \mathrm{D}, 1 / 4 \mathrm{D}$, $1 / 2 \mathrm{D}$ and $\mathrm{D}$ (maximum recommended label dose)], plus control treatment.

The experimental units were composed of $3 \mathrm{~L}$ polyethylene pots, filled with soil classified texturally as clay-sandy loam, where four watermelon (Citrullus lanatus) seeds of the Charleston gray variety were sown per pot. The herbicides were applied by a $\mathrm{CO}_{2}$ pressure pressurized spray, calibrated at $40 \mathrm{kPa}$ of pressure with Teejet TurboJet (TT) 110.02 spray, and $150 \mathrm{~L} \mathrm{ha}^{-1}$ syrup volume. Plants were irrigated daily up to field capacity.

At 30 days after the emergence of the plants, the samples were collected. The analyzed variables were shoot length $(\mathrm{cm})$, root length $(\mathrm{cm})$, root volume $(\mathrm{ml})$, shoot dry mass $(\mathrm{g})$ and root dry mass $(\mathrm{g})$. The shoot length was obtained by measuring the total length from the intercession between stem and shoot to the apical bud $(\mathrm{cm})$; the root length was obtained by measuring the total length of the roots $(\mathrm{cm})$ from the intercession between stem and root to 
S. R. S. RIBEIRO et al.

the apex of the main root; the root volume was measured by the method of the test tube, where the displacement of a known volume represents the root volume measured in $\mathrm{ml}$; the shoot dry mass and root dry mass was obtained $(\mathrm{g})$ by placing the plants in an oven drying with forced air circulation at $65^{\circ} \mathrm{C}$ until reaching constant mass, when they were immediately weighed in an analytical balance.

All data were analyzed by analysis of variance $(\mathrm{p} \leq$ $0.05)$. When $F$ was significant, the treatment means were compared by the Tukey test $(\mathrm{p} \leq 0.05)$. Statistical analyses were performed using the statistical program Sisvar (FERREIRA, 1998).

\section{Results and Discussion}

In the shoot length of watermelon, the reduced length was in plants grown under residue of $1 / 8$ of the recommended dose of [imazapyr + imazapic] when compared to the control treatment, with the nondevelopment of the first pair of true leaves and smaller stem size. This is because ALS-inhibitor herbicides act on the biosynthesis of the branched-chain amino acids (valine, leucine, and isoleucine), by reducing protein synthesis in plants, which has implications on physiological vegetative growth (DYER; WELLER, 2005). Guerra et al. (2011) also verified phytotoxic symptoms in cucumber plants when cultivated after 21 days of application of ALS-inhibitor herbicides, demonstrating the potential sensitivity of cucumber to these herbicides if grown in short periods of time. The herbicide damages were severe at all doses tested for diclosulam and metribuzin, and there was no emergence of plants under the residual of this herbicide. As there was no emergence of plants grown under diclosulam and metribuzin residual, the shoot height, root length, root volume, root and shoot dry mass were not evaluated (Table 1).

Table 1. Shoot length $(\mathrm{cm})$ of watermelon cultivated under herbicides residue applied in different doses. Seropédica (RJ), 2019.

\begin{tabular}{cccc}
\hline Dose $\left(\mathrm{g}\right.$ a.i. ha $\left.{ }^{-1}\right)$ & \multicolumn{2}{c}{ Herbicides } \\
\cline { 2 - 3 } diclosulam & 18.67 & [imazapyr + imazapic] & $18.67 \mathrm{a}$ \\
$1 / 8 \mathrm{D}$ & $*$ & $12.63 \mathrm{~b}$ & $*$ \\
$1 / 4 \mathrm{D}$ & $*$ & $*$ & $*$ \\
$1 / 2 \mathrm{D}$ & $*$ & $*$ & $*$ \\
D & $*$ & $*$ & $*$ \\
\hline C.V. $(\%)$ & & 6.87 \\
\hline
\end{tabular}

*plant death. Means followed by the same letter do not differ in the column by Tukey test $(\mathrm{p} \leq 0.005)$. $(n=4)$. C.V.: coefficient of variation.

Mendes et al. (2015) found that $C$. juncea and $C$. sativus were more than $80 \%$ controlled when the lowest dose of metribuzin $(12.5 \%$ of the recommended dose) was applied. The control of the species was $95 \%$ in the treatments with the application of $50 \%$ of the dose, reaching $100 \%$ control as the herbicide dose increased, allowing the use of $C$. sativus and $C$. juncea species to monitor metribuzin herbicide residues in clayey soil (MENDES et al., 2015).
In the treatment with $1 / 8$ of the commercial dose of the herbicides, only seeds seeded under residual [imazapyr + imazapic] presented root length, which did not differ in relation to the control treatment. Seedlings grown under diclosulam and metribuzin did not emerge at all doses tested (Table 2). In root volume, roots of the plants cultivated under residual of imazapyr + imazapic were observed in $1 / 8$ of the label dose when compared to the control treatment. For the other herbicides, there was the death of plants in all treatments (Table 3).

Table 2. Root length $(\mathrm{cm})$ of watermelon cultivated under herbicides residue applied in different doses. Seropédica (RJ), 2019.

\begin{tabular}{cccc}
\hline \multirow{2}{*}{ Dose $\left(\mathrm{g}\right.$ a.i. $\left.\mathrm{ha}^{-1}\right)$} & \multicolumn{3}{c}{ Herbicides } \\
\cline { 2 - 4 } & diclosulam & [imazapyr + imazapic $]$ & metribuzin \\
\hline 0 & 16.73 & $16.73 \mathrm{a}$ & 16.73 \\
$1 / 8 \mathrm{D}$ & $*$ & $16.03 \mathrm{a}$ & $*$ \\
$1 / 4 \mathrm{D}$ & $*$ & $*$ & $*$ \\
$1 / 2 \mathrm{D}$ & $*$ & $*$ & $*$ \\
D & $*$ & 5.15 & \\
\hline C.V. (\%)
\end{tabular}

*plant death. Means followed by the same letter do not differ in the column by Tukey test $(\mathrm{p} \leq 0.005)$. $(n=4)$. C.V.: coefficient of variation. 
S. R. S. RIBEIRO et al.

Table 3. Root volume (mL) of watermelon cultivated under herbicides residue applied in different doses. Seropédica (RJ), 2019.

\begin{tabular}{|c|c|c|c|}
\hline \multirow{2}{*}{ Dose (g a.i. ha ${ }^{-1}$ ) } & \multicolumn{3}{|c|}{ Herbicides } \\
\hline & diclosulam & [imazapyr + imazapic] & metribuzin \\
\hline 0 & 0.58 & $0.58 \mathrm{~b}$ & 0.58 \\
\hline $1 / 8 \mathrm{D}$ & $*$ & $1.00 \mathrm{a}$ & * \\
\hline $1 / 4 \mathrm{D}$ & $*$ & * & * \\
\hline $1 / 2 \mathrm{D}$ & $*$ & $*$ & $*$ \\
\hline $\mathrm{D}$ & $*$ & * & * \\
\hline C.V. $(\%)$ & & 21.53 & \\
\hline
\end{tabular}

*plant death. Means followed by the same letter do not differ in the column by Tukey test $(\mathrm{p} \leq 0.005)$. $(n=4)$. C.V.: coefficient of variation.

Plants cultivated under [imazapyr + imazapic] residual of $1 / 8 \mathrm{D}$ dose did not differ from the control plants in dry shoot mass and were controlled under the other doses applied. For the other herbicides, the watermelon was controlled in all treatments (Table 4). The herbicide is said to be persistent when it may be found to exist in soil in its original or a closely related but phytotoxic form longer than one crop season after its original application (SONDHIA, 2014).

Table 4. Shoot dry mass (g) of watermelon cultivated under herbicides residue applied in different doses. Seropédica (RJ), 2019.

\begin{tabular}{cccc}
\hline \multirow{2}{*}{ Dose $\left(\mathrm{g}\right.$ a.i. $\left.\mathrm{ha}^{-1}\right)$} & \multicolumn{3}{c}{ Herbicides } \\
\cline { 2 - 4 } diclosulam & 0.42 & [imazapyr + imazapic] & metribuzin \\
\hline $1 / 8 \mathrm{D}$ & $*$ & $0.42 \mathrm{a}$ & 0.42 \\
$1 / 4 \mathrm{D}$ & $*$ & $0.36 \mathrm{a}$ & $*$ \\
$1 / 2 \mathrm{D}$ & $*$ & $*$ & $*$ \\
$\mathrm{D}$ & $*$ & $*$ & $*$ \\
\hline C.V. $(\%)$ & & 10.46 &
\end{tabular}

*plant death. Means followed by the same letter do not differ in the column by Tukey test $(\mathrm{p} \leq 0.005)$. $(n=4)$. C.V.: coefficient of variation.

In soil treated with the $1 / 8 \mathrm{D}$ dose of each herbicide, root dry mass was observed only in plants cultivated under [imazapyr + imazapic] residue; however, the accumulation was lower than in control plants (Table 5). For diclosulam and metribuzin, watermelon was controlled in all treatments. According to Souza et al. (2016), imazethapyr and its mixture with imazapic caused reductions in the dry matter above $94 \%$ of the sorghum plants used as indicators even after 150 days of application, where the imazapic caused lower inhibition of sorghum growth, indicating a lower residual effect of this herbicide in soils.

Table 5. Root dry mass (g) of watermelon cultivated under herbicides residue applied in different doses. Seropédica (RJ), 2019.

\begin{tabular}{cccc}
\hline \multirow{2}{*}{ Dose $\left(\mathrm{g}\right.$ a.i. $\left.\mathrm{ha}^{-1}\right)$} & \multicolumn{3}{c}{ Herbicides } \\
\cline { 2 - 4 } & diclosulam & [imazapyr + imazapic $]$ & metribuzin \\
\hline 0 & 0.06 & $0.06 \mathrm{a}$ & $* 06$ \\
$1 / 8 \mathrm{D}$ & $*$ & $0.04 \mathrm{~b}$ & $*$ \\
$1 / 4 \mathrm{D}$ & $*$ & $*$ & $*$ \\
$1 / 2 \mathrm{D}$ & $*$ & $*$ & $*$ \\
$\mathrm{D}$ & $*$ & 3.19 & \\
\hline C.V. $(\%)$ & & $*$ & \\
\hline
\end{tabular}

*plant death. Means followed by the same letter do not differ in the column by Tukey test $(\mathrm{p} \leq 0.005)$. $(n=4)$. C.V.: coefficient of variation. 
The sorption process can be influenced by soil temperature, humidity, and pH (KRAEMER et al., 2009). The sorption of herbicides from the chemical group of imidazolinones to soil colloids is one of the main factors that interfere with the persistence of these products and protects them from biodegradation processes. The slow degradation of the molecules may have influenced the control of watermelon in the higher doses of [imazapyr + imazapic] tested in this study, as well as the increase of the herbicidal dose.

The observed data for watermelon sensitivity to metribuzin in all analyzed variables, where there was $100 \%$ control of the plants at the doses tested, corroborate with the results obtained by Mendes et al. (2015), which consider the species $C$. sativus with high sensitivity to this herbicide, when applied 12.5, 25, 50 and $100 \%$ of recommended dose. Similar data were observed by Guerra et al. (2011), which used bioindicator species to trifloxysulfuron-sodium and pyrithiobac-sodium with the same mechanism of action as metribuzin, and the $C$. sativus being the most sensitive species to herbicide residues up to 37 times lower than the recommended dose in relation to other species studied (Glycine max, Zea mays, and Phaseolus vulgaris).

Bioassays performed by Ben et al. (2015), showed that $C$. sativus is highly sensitive related to the persistence of metribuzin in different types of soil (Red Latosol and Quartzarenic Neosol), indicated by the death of the species when submitted to the treatments with 0,480 and $360 \mathrm{~g} \mathrm{ha}^{-1}$. The sensitivity of $C$. sativus to the herbicide was verified in addition to its low persistence in sandy soils, persistence not influenced by the period between application and sowing of the bioindicator.

Inhibition of ALS by the herbicides diclosulam and [imazapyr + imazapic] lead to the depletion of the branchedchain amino acids, and plant death is thought to result from eventual protein starvation. Besides that, more subtle physiological effects associated with these herbicides is the accumulation of the ALS enzyme substrate which leads to cell toxicity (DYER; WELLER, 2005).

The main effects of metribuzin are attributed to the long residual in the soil which caused effects in watermelon plants by targeting the D1 protein in PSII of the photosynthetic electron transport pathway. The result of photosynthetic inhibition affects plants by leading them to starve due to the loss of fixed carbon. Besides that, there is increased toxicity as a result of electron transfer blockage which prevent the conversion of light into electrochemical energy and resulting in the production of high-energy reactive oxygen species (BROMILOW, 2004).

\section{Conclusions}

Watermelon is highly sensitive to the herbicides diclosulam, metribuzin and the commercial mixture of the herbicides [imazapyr + imazapic], indicating that the persistence of these herbicides in the soil can affect the growth of watermelon. The watermelon has potential use as a bioindicator to residual of the herbicides diclosulam, metribuzin and the formulated mixture of [imazapyr + imazapic] in clay soil.

\section{References}

Ben, A.K.A.N.; Possamani, A.C.S.; Cardoso, W.S.; Ben, R.; Castro, E.B.; Belapart, D.; Mendes, K.F. Lixiviação e persistência de metribuzin por bioensaio. Scientia Plena, v.11, n.05, 2015.

Blanco, F.M.G.; Velini, E.D.; Filho, A.B. Persistência do herbicida sulfentrazone em solo cultivado com cana-deaçúcar. Bragantia, v.69, n.1, p.71-75, 2010.

Bromilow, R.H. Paraquat and sustainable agriculture. Pest Management Science, v.60, p. 340-349, 2004.

Dan, H.A.; Dan, L.G.M.; Barroso, A.L.L.; Procópio, S.O.; Oliveira Jr., R.S.; Braz, G.B.P.; Alonso, D.G. Atividade residual de herbicidas usados na soja sobre o girassol cultivado em sucessão. Ciência Rural, v.42, n.11, p.19291935, 2012.

Dovala, A.C.; Monteiro, A. Controle químico de Striga asiatica por recurso a sementes revestidas de milhos resistentes ao imazapir. Revista de Ciências Agrárias, v.36, n.4, p.466-474, 2013.

Dyer, W.E.; Weller, S.C. Plant response to herbicide. In: Jenks, M.A.; Hasegawa, P.M. Plant abiotic stress. Oxford: Blackwell Publishing, p 171-214. 2005.

Ferreira, D.F. Sisvar - sistema de análise de variância para dados balanceados. Lavras: UFLA, 1998. 19 p.

Guerra, N.; Oliveira Jr., R.S.; Constantin, J.; Oliveira Neto, A.M.; Dan, H.A.; Alonso, D.G.; Jumes, T.M.C. Seleção de espécies bioindicadoras para os herbicidas trifloxysulfuronsodium e pyrithiobac-sodium. Revista Brasileira de Herbicidas, v.10, n.1, p.37-48, 2011.

Kraemer, A.F.; Marchesan, E.; Avila, L.A.; Machado, S.L.O.; Grohs, M. Destino ambiental dos herbicidas do grupo das imidazolinonas. Planta Daninha, v.27, n.3, p.629 $-639,2009$.

Li, X.Q.; Ng, A.; King, R.; Durnford, D.G. A rapid and simple bioassay method for herbicide detection. Biomarker Insights, v.3, p.287-291, 2008.

Melo, C.A.D.; Medeiros, W.N.; Tuffi Santos, L.D.; Ferreira, F.A.; Ferreira, G.L.; Paes, F.A.S.V.; Reis, M.R. Efeito residual de sulfentrazone, isoxaflutole e oxyfluorfen em três solos. Planta Daninha, v.28, n.4, p.835-842, 2010.

Mendes, K.F.; Souza, T.C.N. de; Possamai, A.C.S.; Inoue, M.H.; Nunes, A.K. de A.; Mertens, T.B. Seleção de plantas indicadoras para o monitoramento do mesotrione $\mathrm{e}$ metribuzim em solo argiloso. Revista de Ciências Agroambientais, v.13, n.1, p.53-59, 2015.

Monquero, P.A.; Munhoz, W.S.; Hirata. A.C.S. Persistência de imazaquim e diclosulam em função da umidade do solo. 
Revista Agro@mbiente On-line, v.7,n.3,p.331-337, 2013.

Oliveira Junior, R.S.; Regitano, J.B. Dinâmica de pesticidas no solo. In: MELO, V.F.; ALLEONI, L.R.F. (Ed.). Química e mineralogia do solo: aplicações. Viçosa, MG: Sociedade Brasileira de Ciência do Solo, 2009. p.187-248.

Pires, F.R.; Procópio, S.O.; Santos, J.B.; Souza, C.M.; Dias, R.R. Avaliação da fitorremediação de tebuthiuron utilizando Crotalaria juncea como planta indicadora. Ciência Agronômica, v.39, n.2, p.245-250, 2008.

Prata, F. Glyphosate sorption and desorption in soils with distinct phosphorus levels. Scientia Agricola, v.60, n.1, p.175-180, 2003.

Santos, D.P.; Braga, R.R.; Guimarães, F.A.R.; Passos, A.B.R.J.; Silva, D.V.; Santos, J.B.; Nery, M.C. Determinação de espécies bioindicadoras de resíduos de herbicidas auxínicos. Revista Ceres, v.60, n.3, p.354-362, 2013.

Senseman, S.A. Herbicide Handbook. Weed Science Society of America, Champaign, 2007. 458 p.

Silva Junior, A.C.; Queiroz, J.R.G.; Martins, D. Quantidade de chuva e lixiviação do herbicida metribuzim através de planta bioindicadora. Revista Brasileira de Engenharia Agrícola e Ambiental, v.19, n.6, p.592-597, 2015.

Sondhia, S. Herbicides residues: monitoring in soil, water, plants and non-targeted organisms and human health implications: an Indian perspective. In: Extended summary of Biennial Conference of Indian Society of Weed Science Jabalpur, India. Anais... Jabalpur: Indian Society of Weed Science, 2014.

Souza, M.F.; Neto, M.D.C.; Marinho, M.I.; Saraiva, D.T.; Faria, A.T.; Silva, A.A.; Silva, D.V. Persistence of imidazolinones in soils under a Clearfield system of rice cultivation. Planta Daninha, v.34, n.3, p.589-596, 2016.

Tropaldi, L; Velini, E.D.; Carbonari, C.A.; Araldi. R.; Corniani. N.; Girotto. M.; Silva. I.P.F. Detecção da tolerância de diferentes espécies de capim-colchão a herbicidas inibidores do fotossistema II utilizando a técnica da fluorescência. Ciência Rural, v.45, n.5, p.767-773, 2015. 